\title{
ॠUSGS Extusans
}

Preparced in cooperation with Santee Cooper

\section{Bathymetric, Velocity, Streamflow, and Dissolved Oxygen Data on the Pee Dee River near Bostick Boat Landing. Florence County, South Carolina, May-August 2007}

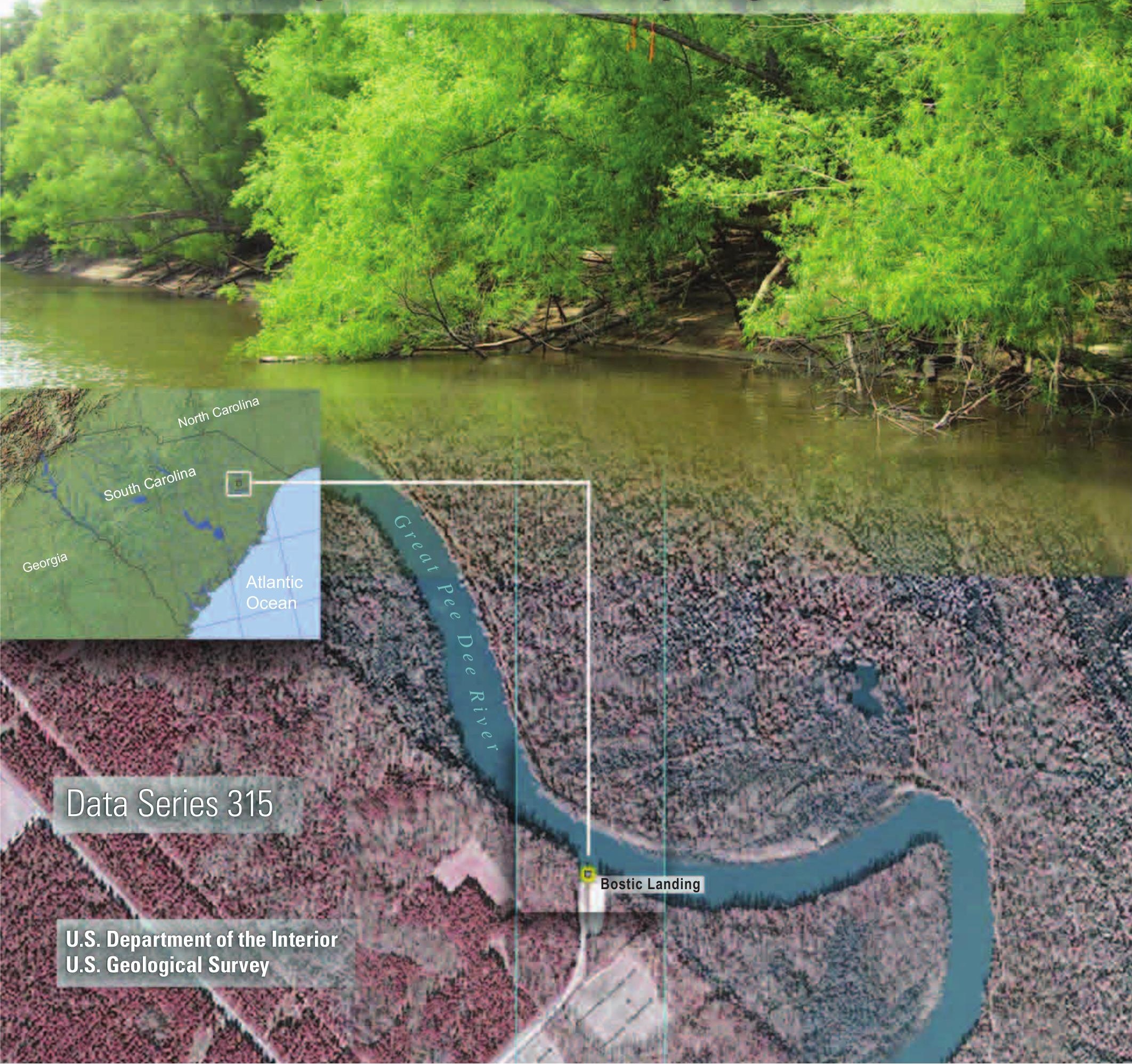
सites th 
Cover image. Bostic Landing on the Great Pee Dee River, Florence County, South Carolina, and 2006 USGS Digital Orthoimagery Quarter Quadrangle. 


\section{Bathymetric, Velocity, Streamflow, and Dissolved Oxygen Data on the Pee Dee River near Bostick Boat Landing, Florence County, South Carolina, May-August 2007}

By John M. Shelton

Prepared in cooperation with Santee Cooper

Data Series 315 


\title{
U.S. Department of the Interior \\ KEN SALAZAR, Secretary
}

\author{
U.S. Geological Survey \\ Suzette M. Kimball, Acting Director
}

U.S. Geological Survey, Reston, Virginia: 2009

For more information on the USGS - the Federal source for science about the Earth, its natural and living resources, natural hazards, and the environment, visit http://www.usgs.gov or call 1-888-ASK-USGS

For an overview of USGS information products, including maps, imagery, and publications, visit http://www.usgs.gov/pubprod

To order this and other USGS information products, visit http://store.usgs.gov

Any use of trade, product, or firm names is for descriptive purposes only and does not imply endorsement by the U.S. Government.

Although this report is in the public domain, permission must be secured from the individual copyright owners to reproduce any copyrighted materials contained within this report.

Suggested citation:

Shelton, J.M., 2009, Bathymetric, velocity, streamflow, and dissolved oxygen data on the Pee Dee River near Bostick Boat Landing, Florence County, South Carolina, May-August 2007: U.S. Geological Survey Data Series 315, 8 p. 


\section{Contents}

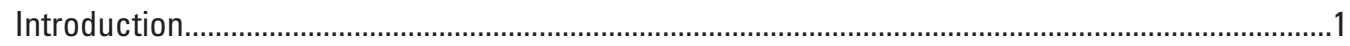

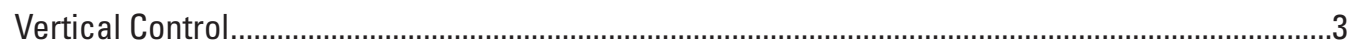

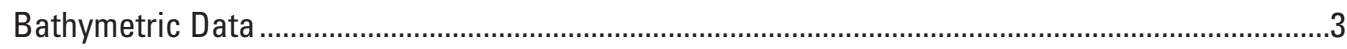

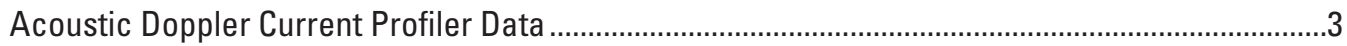

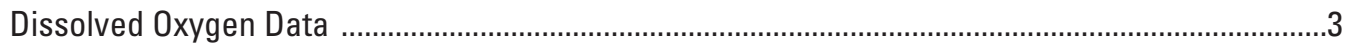

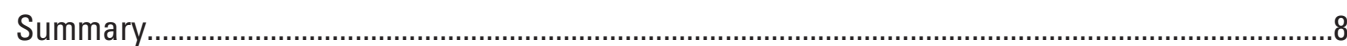

\section{Figures}

\section{1-5. Maps showing-}

1. Location of bathymetric, velocity, streamflow, and dissolved oxygen study area on the Pee Dee River near Bostick Boat Landing, Florence County, South Carolina........

2. Bathymetry and approximate transect locations on the Pee Dee River near Bostick Boat Landing .2

3. Mean measured velocities for "high" flow, April 25, 2007..........................................5

4. Mean measured velocities for "medium" flow, May 31, 2007 ....................................6

5. Mean measured velocities for "low" flow, August 24, 2007 ........................................7

\section{Tables}

1. Streamflow summary of 15 transects for 3 flow regimes ................................................

2. Dissolved oxygen summary of 15 transects for 3 flow regimes...................................... 


\section{Conversion Factors}

\begin{tabular}{|c|c|c|}
\hline Multiply & By & To obtain \\
\hline \multicolumn{3}{|c|}{ Length } \\
\hline foot $(\mathrm{ft})$ & 0.3048 & meter $(\mathrm{m})$ \\
\hline \multicolumn{3}{|c|}{ Flow rate } \\
\hline foot per second (ft/s) & 0.3048 & meter per second $(\mathrm{m} / \mathrm{s})$ \\
\hline cubic foot per second $\left(\mathrm{ft}^{3} / \mathrm{s}\right)$ & 0.02832 & cubic meter per second $\left(\mathrm{m}^{3} / \mathrm{s}\right)$ \\
\hline
\end{tabular}

Vertical coordinate information is referenced to the North American Vertical Datum of 1988 (NAVD 88).

Concentrations of chemical constituents in water are given in milligrams per liter (mg/L). 


\title{
Bathymetric, Velocity, Streamflow, and Dissolved Oxygen Data on the Pee Dee River near Bostick Boat Landing, Florence County, South Carolina, May-August 2007
}

\author{
By John M. Shelton
}

\section{Introduction}

Santee Cooper is planning to construct an electricity generating station in southeastern Florence County near the Kingsburg community. As part of this project, a water-intake structure will be constructed on the Pee Dee River near the Bostick Boat Landing, which is located east of the intersection of State secondary roads S-21-57 and S-21-66 (fig. 1). Velocity, bathymetric, and dissolved oxygen data are needed to help determine the location for the water-intake structure. The U.S. Geological Survey (USGS), in cooperation with Santee Cooper, collected these data at three different flow regimes during the period of May through August 2007.

Data were collected along 15 transects located at 50-foot intervals starting 400 feet upstream from the boat landing and continuing to 300 feet downstream from the boat landing (fig. 2). All data were geographically referenced using a differentially corrected global positioning system (GPS).

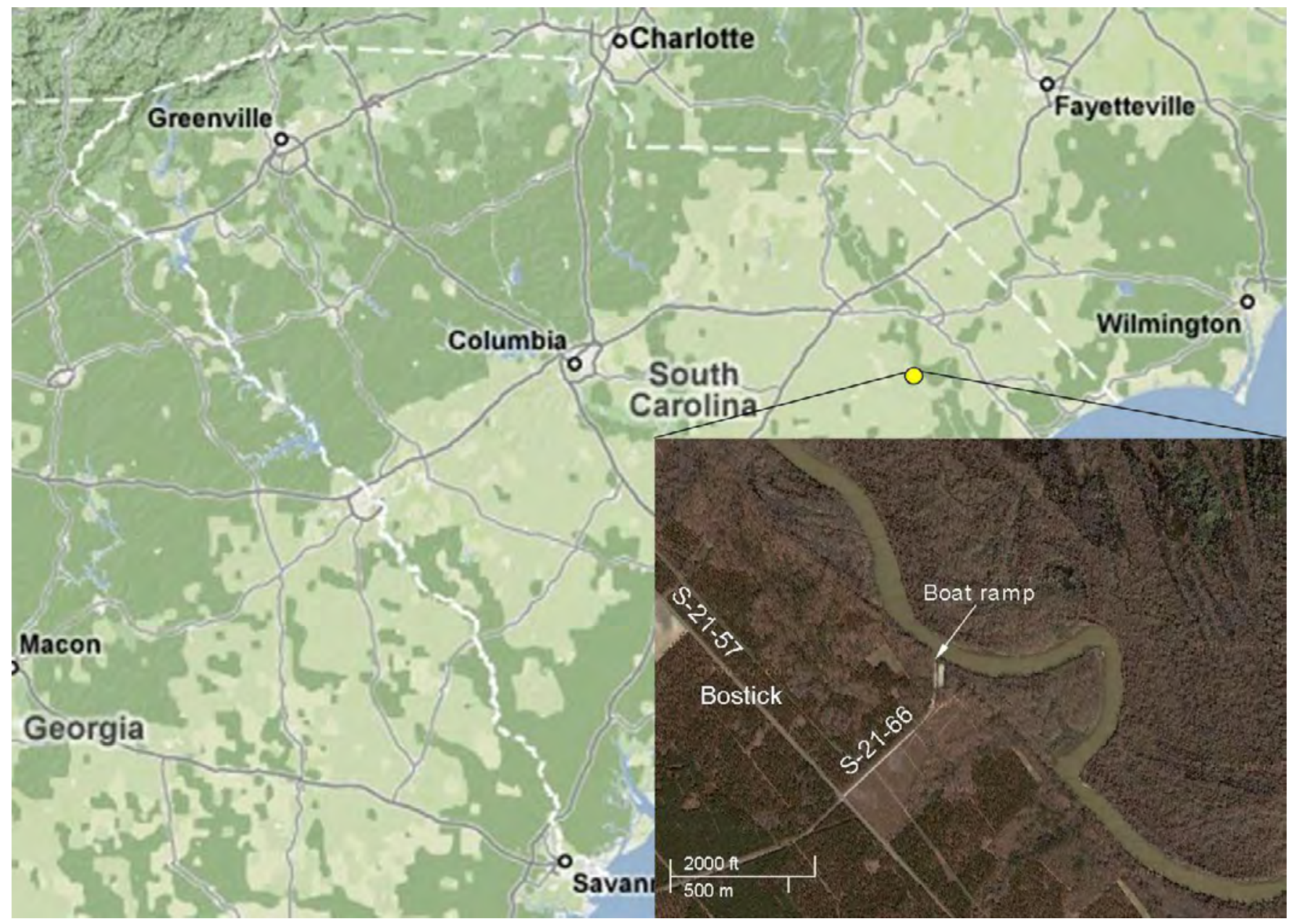

Figure 1. Location of bathymetric, velocity, streamflow, and dissolved oxygen study area on the Pee Dee River near Bostick Boat Landing, Florence County, South Carolina. 


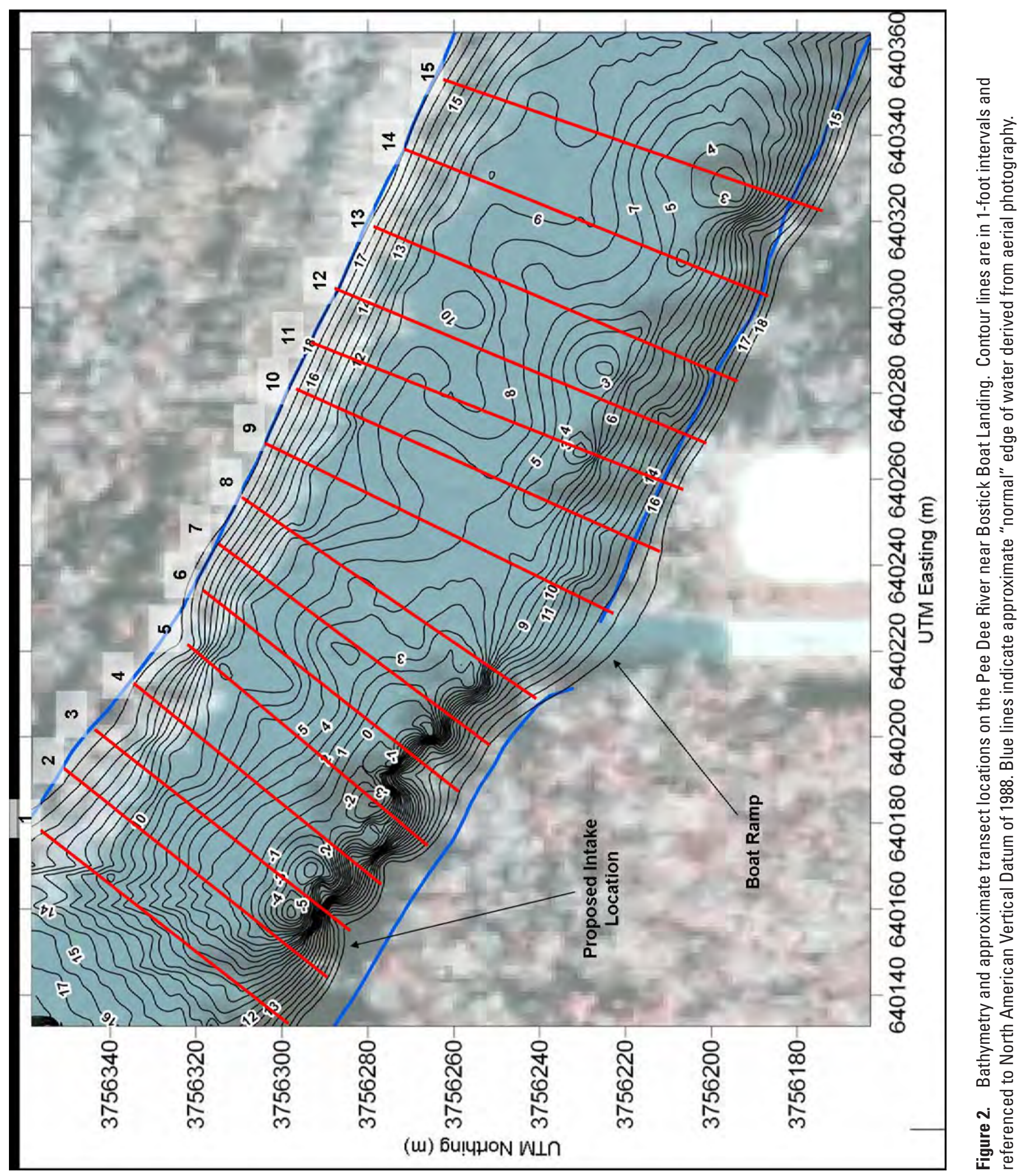




\section{Vertical Control}

A temporary bench mark was established on April 25, 2007, using differential GPS survey techniques. A reference mark on the concrete curb of the boat landing was established using standard survey leveling techniques (elevation $37.410 \mathrm{ft}$ ). A brass tablet reference mark was established by Santee Cooper personnel (elevation $16.377 \mathrm{ft}$ ). These reference marks were used to determine water-surface elevations for each of the flow regimes that were measured. Elevations are referenced to the North American Vertical Datum of 1988 (NAVD 88). ${ }^{1}$

\section{Bathymetric Data}

Bathymetric data were collected on April 25 and May 3, 2007, by interfacing a twelve-channel GPS receiver and data logger to a dual-frequency fathometer. The horizontal coordinates and depth soundings were time tagged and recorded to the data logger. When these data were processed, the depth soundings were assigned a horizontal coordinate by interpolating the time readings from both sets of measurements. The bathymetric map produced from these data depicts $1-\mathrm{ft}$ contour elevations referenced to NAVD 88 (fig. 2). The "0" (zero) contour line represents mean sea level (MSL).

\section{Acoustic Doppler Current Profiler Data}

An acoustic Doppler current profiler (ADCP) was used to collect depth, velocity, and streamflow data for the defined study area. Data were collected from a boat using a Teledyne/RD Instruments ADCP. All data were geo-referenced using a differentially corrected GPS in real-time. The ADCP transmits an acoustic pulse through the water column. Each pulse is divided into multiple bins or depth cells. The ADCP continuously transmits these pulses as each transect is navigated. Velocities are computed for each individual depth cell. Because of the frequency of the pulses and the multiple velocity measurements with depth, each transect is composed of hundreds of individual velocity measurements. The velocity data for this study are available upon request from the USGS, but due to the extremely large size of the dataset, are not included in this report.

Data were collected on April 25, May 31, and August 24, 2007. For the purpose of this study, flows on April 25 were classified as "high," flows on May 31 were classified as "medium," and flows on August 24 were classified as "low." Table 1 summarizes the streamflow data collected for the three flow regimes.

The "high" flow streamflow measurements ranged from 11,500 cubic feet per second $\left(\mathrm{ft}^{3} / \mathrm{s}\right)$ to $12,500 \mathrm{ft}^{3} / \mathrm{s}$ with a mean of $12,010 \mathrm{ft}^{3} / \mathrm{s}$. The average water-surface elevation for these measurements was $27.04 \mathrm{ft}$ NAVD 88 . The water-surface

\footnotetext{
${ }^{1}$ NAVD 88 uses one base monument located at Father's Point, Quebec, Canada, as mean sea level (MSL). All other bench marks in North America are referenced to that one base monument for NAVD 88 elevations.
}

elevation dropped $0.36 \mathrm{ft}$ during the course of the measurements (4.2 hours). Measured mean velocities ranged from approximately 2 feet per second (ft/s) to $4 \mathrm{ft} / \mathrm{s}$ and were generally uniform in direction (fig. 3).

The "medium" flow streamflow measurements ranged from $1,940 \mathrm{ft}^{3} / \mathrm{s}$ to $2,250 \mathrm{ft}^{3} / \mathrm{s}$ with a mean of $2,080 \mathrm{ft}^{3} / \mathrm{s}$. The average water-surface elevation for these measurements was $13.59 \mathrm{ft}$ NAVD 88. The water-surface elevation rose $0.94 \mathrm{ft}$ during the course of the measurements (4.3 hours). Measured mean velocities ranged from approximately $0.4 \mathrm{ft} / \mathrm{s}$ to $2.1 \mathrm{ft} / \mathrm{s}$. Measured velocities were slower with more directional variability in the upper transects (transects 1-8) and then accelerated in the lower transects primarily due to shallower depths (fig. 4).

The "low" flow streamflow measurements ranged from $1,490 \mathrm{ft}^{3} / \mathrm{s}$ to $1,620 \mathrm{ft}^{3} / \mathrm{s}$ with a mean of $1,560 \mathrm{ft}^{3} / \mathrm{s}$. The average water-surface elevation for these measurements was $12.30 \mathrm{ft}$ NAVD 88. The water-surface elevation dropped $0.04 \mathrm{ft}$ during the course of the measurements (6.5 hours). Measured mean velocities ranged from approximately $0.4 \mathrm{ft} / \mathrm{s}$ to $1.7 \mathrm{ft} / \mathrm{s}$. Measured velocities were slower with more directional variability in the upper transects (transects 1-8) and then accelerated in the lower transects primarily due to shallower depths (fig. 5).

\section{Dissolved Oxygen Data}

The amount of oxygen that can be dissolved in water is affected by many factors including ambient temperature, atmospheric pressure, and ion activity. Dissolved oxygen (DO) concentrations can be increased in water by atmospheric aeration and photosynthetic activities of aquatic plants; however, DO concentrations also can be decreased by many chemical and biological reactions that depend directly or indirectly on available oxygen.

DO data were collected on April 25-26, May 30, and August 23, 2007. As previously stated, for the purpose of this study, flows on April 25-26 were classified as "high," flows on May 30 were classified as "medium," and flows on August 23 were classified as "low." Table 2 summarizes the DO data collected for the three flow regimes. DO measurements are reported in milligrams per liter $(\mathrm{mg} / \mathrm{L})$ and percent saturation. Milligrams per liter is the quantity of oxygen dissolved in 1 liter of water. Percent saturation is the amount of oxygen in a liter of water relative to the total amount of oxygen that the water can hold at that temperature. Occasions of super saturation (greater than 100-percent DO saturation) often are related to excess photosynthetic production of oxygen by aquatic plants as a result of nutrient enrichment, sunlight, and warm water temperatures, which often occur in streams during lowflow conditions. ${ }^{2}$

\footnotetext{
${ }^{2}$ Wagner, R.J., Boulger, R.W., Jr., Oblinger, C.J., and Smith, B.A., 2006, Guidelines and standard procedures for continuous water-quality monitorsStation operation, record computation, and data reporting: U.S. Geological Survey Techniques and Methods 1-D3, 51 p. + 8 attachments; accessed November 29, 2007, at http://pubs.water.usgs.gov/tm1d3
} 
Table 1. Streamflow summary of 15 transects for 3 flow regimes.

[ft³/s, cubic feet per second; EST, Eastern Standard Time; NAVD 88, North American Vertical Datum of 1988; ft, feet]

\begin{tabular}{|c|c|c|c|c|c|c|}
\hline \multirow{2}{*}{ Transect } & \multicolumn{2}{|c|}{$\begin{array}{l}\text { “High" flow, } \\
\text { April 25, } 2007\end{array}$} & \multicolumn{2}{|c|}{$\begin{array}{l}\text { “Medium" flow, } \\
\text { May 31, } 2007\end{array}$} & \multicolumn{2}{|c|}{$\begin{array}{l}\text { “Low" flow, } \\
\text { August 24, } 2007\end{array}$} \\
\hline & $\begin{array}{c}\text { Discharge } \\
\left(\mathrm{ft}^{3} / \mathrm{s}\right)\end{array}$ & $\begin{array}{l}\text { Time } \\
\text { (EST) }\end{array}$ & $\begin{array}{l}\text { Discharge } \\
\left(\mathrm{ft}^{3} / \mathrm{s}\right)\end{array}$ & $\begin{array}{l}\text { Time } \\
\text { (EST) }\end{array}$ & $\begin{array}{c}\text { Discharge } \\
\left(\mathrm{ft}^{3} / \mathrm{s}\right)\end{array}$ & $\begin{array}{l}\text { Time } \\
\text { (EST) }\end{array}$ \\
\hline 1 & 11,900 & $16: 07$ & 1,940 & $10: 06$ & 1,550 & $8: 24$ \\
\hline 2 & 12,100 & $15: 53$ & 2,100 & $11: 10$ & 1,620 & $9: 44$ \\
\hline 3 & 12,000 & $15: 44$ & 2,090 & $11: 23$ & 1,580 & $10: 13$ \\
\hline 4 & 11,800 & $15: 33$ & 2,010 & $11: 46$ & 1,580 & $10: 30$ \\
\hline 5 & 11,900 & $15: 24$ & 1,960 & $11: 56$ & 1,490 & $10: 45$ \\
\hline 6 & 11,900 & $16: 25$ & 1,970 & $12: 06$ & 1,560 & $11: 12$ \\
\hline 7 & 11,800 & $15: 10$ & 2,000 & $12: 19$ & 1,570 & $12: 12$ \\
\hline 8 & 11,500 & $14: 57$ & 1,970 & $12: 32$ & 1,510 & $12: 25$ \\
\hline 9 & 12,100 & $14: 43$ & 2,080 & $12: 58$ & 1,590 & $13: 19$ \\
\hline 10 & 12,300 & $14: 30$ & 2,160 & $13: 08$ & 1,600 & $13: 40$ \\
\hline 11 & 12,100 & $14: 18$ & 2,160 & $13: 27$ & 1,540 & $14: 29$ \\
\hline 12 & 11,800 & $14: 05$ & 2,190 & $13: 40$ & 1,560 & $14: 49$ \\
\hline 13 & 12,200 & $13: 37$ & 2,180 & $13: 52$ & 1,550 & $15: 07$ \\
\hline 14 & 12,200 & 13:04 & 2,150 & $14: 04$ & 1,520 & $15: 22$ \\
\hline 15 & 12,500 & $12: 28$ & 2,250 & $14: 15$ & 1,560 & $15: 37$ \\
\hline Mean discharge $\left(\mathrm{ft}^{3} / \mathrm{s}\right)$ & 12,010 & & 2,080 & & 1,560 & \\
\hline Maximum discharge $\left(\mathrm{ft}^{3} / \mathrm{s}\right)$ & 12,500 & & 2,250 & & 1,620 & \\
\hline Minimum discharge $\left(\mathrm{ft}^{3} / \mathrm{s}\right)$ & 11,500 & & 1,940 & & 1,490 & \\
\hline $\begin{array}{l}\text { Start water-surface elevation } \\
\quad(\mathrm{ft}) \text { (NAVD 88) }\end{array}$ & 27.22 & & 13.12 & & 12.32 & \\
\hline $\begin{array}{l}\text { End water-surface elevation } \\
\text { (ft) (NAVD 88) }\end{array}$ & 26.86 & & 14.06 & & 12.28 & \\
\hline $\begin{array}{l}\text { Average water-surface } \\
\text { elevation (ft) (NAVD 88) }\end{array}$ & 27.04 & & 13.59 & & 12.30 & \\
\hline
\end{tabular}

Table 2. Dissolved oxygen summary of 15 transects for 3 flow regimes.

[mg/L, milligrams per liter]

\begin{tabular}{|c|c|c|c|c|c|c|}
\hline & \multicolumn{2}{|c|}{$\begin{array}{c}\text { “High" flow, } \\
\text { April 25-26, } 2007\end{array}$} & \multicolumn{2}{|c|}{$\begin{array}{l}\text { “Medium" flow, } \\
\text { May 30, } 2007\end{array}$} & \multicolumn{2}{|c|}{$\begin{array}{c}\text { “Low" flow, } \\
\text { August 23, } 2007 \\
\end{array}$} \\
\hline & $\begin{array}{c}\text { Dissolved } \\
\text { oxygen } \\
\text { (mg/L) }\end{array}$ & $\begin{array}{l}\text { Dissolved } \\
\text { oxygen } \\
\text { (percent } \\
\text { saturation) }\end{array}$ & $\begin{array}{c}\text { Dissolved } \\
\text { oxygen } \\
\text { (mg/L) }\end{array}$ & $\begin{array}{l}\text { Dissolved } \\
\text { oxygen } \\
\text { (percent } \\
\text { saturation) }\end{array}$ & $\begin{array}{c}\text { Dissolved } \\
\text { oxygen } \\
\text { (mg/L) }\end{array}$ & $\begin{array}{c}\text { Dissolved } \\
\text { oxygen } \\
\text { (percent } \\
\text { saturation) }\end{array}$ \\
\hline Maximum & 6.4 & 72 & 8.2 & 102 & 10.5 & 144 \\
\hline Minimum & 5.8 & 63 & 7.3 & 89 & 8.7 & 117 \\
\hline Mean & 6.0 & 64 & 7.7 & 95 & 9.5 & 130 \\
\hline Median & 6.0 & 64 & 7.6 & 94 & 9.5 & 130 \\
\hline Standard deviation & 0.08 & 1.07 & 0.26 & 3.73 & 0.46 & 6.73 \\
\hline
\end{tabular}




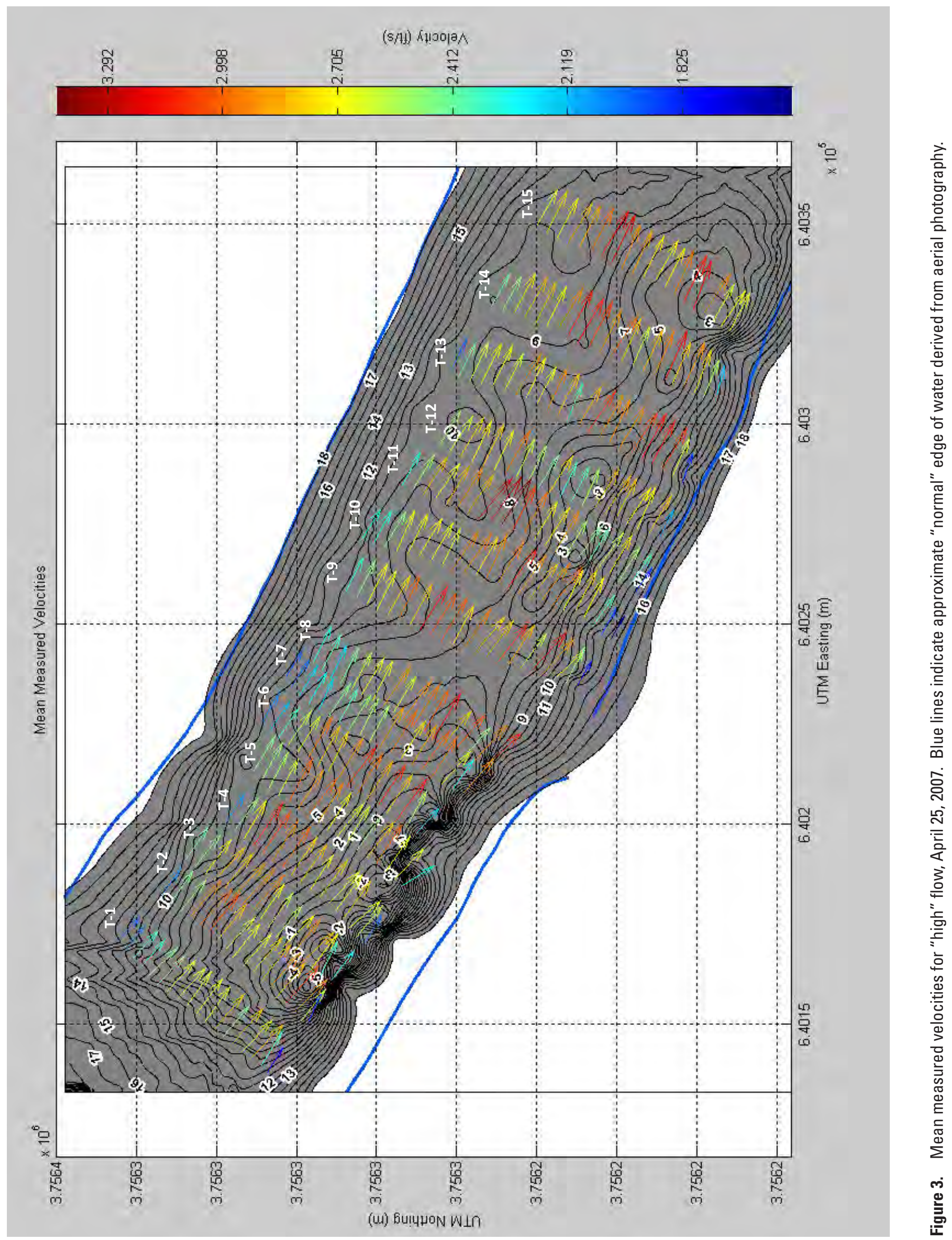




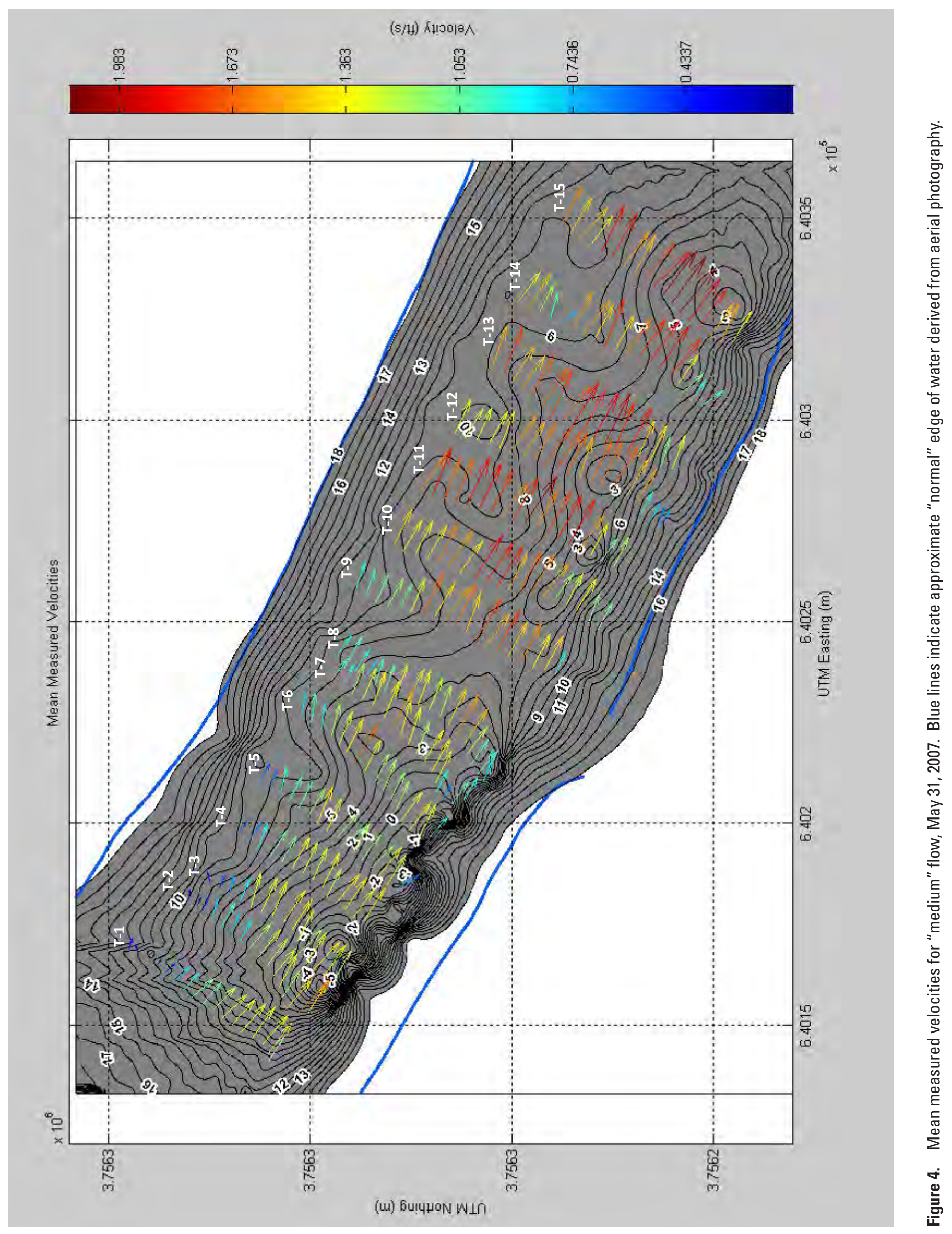




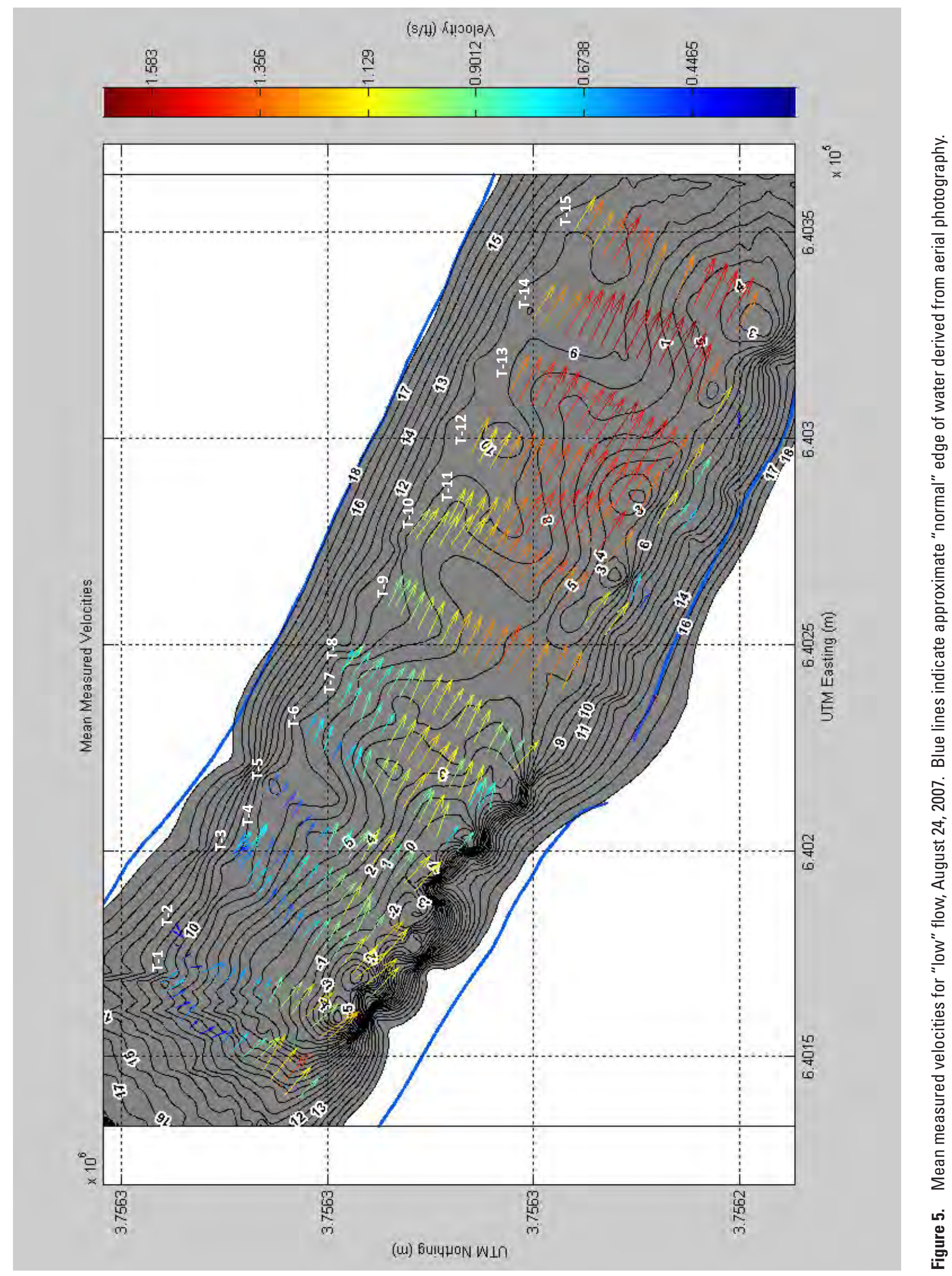


The "high" flow DO measurements ranged from $5.8 \mathrm{mg} / \mathrm{L}$ to $6.4 \mathrm{mg} / \mathrm{L}$ with a median of $6.0 \mathrm{mg} / \mathrm{L}$. Due to the length of time involved in making multiple DO measurements in highflow conditions, the measurements were made over a 2-day period. The average water-surface elevation for these measurements was $26.23 \mathrm{ft}$ NAVD 88 . The water-surface elevation dropped $1.98 \mathrm{ft}$ during the course of the measurements (28.0 hours). DO concentrations were consistently stable in both the vertical and lateral of each transect as well as between transects. The spatially consistent DO concentrations indicate a well mixed environment in this flow regime.

The "medium" flow DO measurements ranged from $7.3 \mathrm{mg} / \mathrm{L}$ to $8.2 \mathrm{mg} / \mathrm{L}$ with a median of $7.6 \mathrm{mg} / \mathrm{L}$. The watersurface elevation for these measurements was approximately $12.96 \mathrm{ft}$ NAVD 88. DO concentrations increased with each transect in the downstream direction. Concentrations on the left side of the river were approximately 2 percent lower than the concentrations mid-channel and near the right bank. ${ }^{3}$ Increased velocities and increased photosynthetic activities in the shallower depths may account for the higher DO concentrations in the downstream transects.

The "low" flow DO measurements ranged from $8.7 \mathrm{mg} / \mathrm{L}$ to $10.5 \mathrm{mg} / \mathrm{L}$ with a median of $9.5 \mathrm{mg} / \mathrm{L}$. The average watersurface elevation for these measurements was $11.74 \mathrm{ft} \mathrm{NAVD}$ 88. The water-surface elevation dropped $0.09 \mathrm{ft}$ during the course of the measurements (2.25 hours). DO concentrations

\footnotetext{
${ }^{3}$ Left or right bank is defined relative to the observer facing the downstream direction.
}

increased with each transect in the downstream direction. Increased velocities and increased photosynthetic activities in the shallower depths may account for the higher DO concentrations in the downstream transects.

\section{Summary}

Velocity, streamflow, bathymetric, and dissolved oxygen (DO) data were collected along fifteen transects on the Pee Dee River near the Bostick Boat Landing, which is located east of the intersection of State secondary roads S-21-57 and S-21-66 in southeastern Florence County near the Kingsburg community. Velocity, streamflow, and DO data were collected during three flow regimes representing "low," "medium," and "high" flow conditions. In "high" flow conditions, measured mean velocities were generally uniform in direction and consistent through all of the transects. In "medium" and "low" flow conditions, velocities were slower with more directional variability in the upper transects and then accelerated in the lower transects primarily due to shallower depths. DO concentrations increased as streamflow decreased in each of the three flow regimes. DO concentrations in the "high" flow regime were spatially consistent. DO concentrations increased with each transect in the downstream direction in the "medium" and "low" flow regimes. The increased concentrations may be the result of increased velocities and increased photosynthetic activities in the shallower depths.

\footnotetext{
Prepared by:

USGS Publishing Network

Raleigh Publishing Service Center

3916 Sunset Ridge Road

Raleigh, NC 27607

For additional information regarding this publication, contact:

John M. Shelton, Associate Director-Hydrologic Data

USGS South Carolina Water Science Center

Stephenson Center, Suite 129

720 Gracern Road

Columbia, SC 29210

email: jmshelto@usgs.gov

Or visit the USGS South Carolina Water Science Center Web site at:

http://sc.water.usgs.gov/
} 



\section{总}

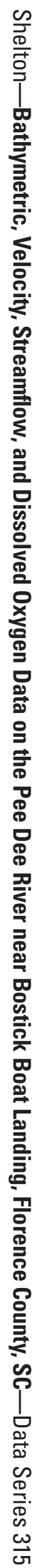

